This work is licensed under a Creative Commons Attribution 4.0 International License.

Fonte: http://theglobaljournals.com/ijsr/issues.php?m=March\&y=2014\&id=23. Acesso em: 27 jul. 2014.

\title{
REFERÊNCIA
}

ARAÚJO, Pollyanna Cardoso et al. Physiological demands and changes resulting from effort in low handicap polo horses. International Journal of Scientific Research, Ahmedabad, v. 3, n. 3, mar. 2014. Disponível em:

<http://theglobaljournals.com/ijsr/file.php?val=March 20141393939704 fabeb 126.pdf >. Acesso em: 27 jul. 2014. 


\section{Physiological Demands and Changes Resulting from Effort in Low Handicap Polo Horses}

Pollyanna Cardoso
Araújo

\section{Camila Alfaro de Oliveira Bello}

\section{Cinthia Beatriz da Silva Dumont}

\section{Renata De Pino Albuquerque Maranhão}

Fabieni Tiemy Menezes Okiyama

\section{Kaique Nogueira}

\section{Eduardo Maurício Mendes de Lima}

Programa de Pós-Graduação em Saúde Animal, Faculdade de Agronomia e Medicina Veterinária, Universidade de Brasília (UnB), ICC Sul, Campus Universitário Darcy Ribeiro, Cx. Postal 4508, Brasília, DF 70910-970, Brazil.

Programa de Pós-Graduação em Saúde Animal, Faculdade de Agronomia e Medicina Veterinária, Universidade de Brasília (UnB), ICC Sul, Campus Universitário Darcy Ribeiro, Cx. Postal 4508, Brasília, DF 70910-970, Brazil.

Programa de Pós-Graduação em Saúde Animal, Faculdade de Agronomia e Medicina Veterinária, Universidade de Brasília (UnB), ICC Sul, Campus Universitário Darcy Ribeiro, Cx. Postal 4508, Brasília, DF 70910-970, Brazil.

Universidade Federal de Minas Gerais, Departamento Clínica e Cirurgia Veterinárias - EV., Av. Antônio Carlos, 6627 Pampulha 30123-970 - Belo Horizonte, MG - Brasil - Caixa-postal: 567

Programa de Pós-Graduação em Saúde Animal, Faculdade de Agronomia e Medicina Veterinária, Universidade de Brasília (UnB), ICC Sul, Campus Universitário Darcy Ribeiro, Cx. Postal 4508, Brasília, DF 70910-970, Brazil.

Programa de Pós-Graduação em Saúde Animal, Faculdade de Agronomia e Medicina Veterinária, Universidade de Brasília (UnB), ICC Sul, Campus Universitário Darcy Ribeiro, Cx. Postal 4508, Brasília, DF 70910-970, Brazil.

Programa de Pós-Graduação em Saúde Animal, Faculdade de Agronomia e Medicina Veterinária, Universidade de Brasília (UnB), ICC Sul, Campus Universitário Darcy Ribeiro, Cx. Postal 4508, Brasília, DF 70910-970, Brazil.

\section{ABSTRACT}

In order to understand the physiological demands and possible changes resulting from effort in horses and determine the type and intensity of exercise performed in equestrian polo of low handicap, we analyzed the negative logarithm of the activity of hydrogen ions $(\mathrm{pH})$, carbon dioxide partial pressure ( $\mathrm{pCO2}$ ), oxygen partial pressure ( $\mathrm{pO2}$ ), the concentration of plasma bicarbonate ions ( $\mathrm{HCO}-$ ) and serum concentrations of $\mathrm{Na}+\mathrm{Cl}$ - and $\mathrm{K}+$ of seven healthy horses after a polo match of low handicap. Variables pCO2, pO2 and HCO3- were the only parameters that were significantly different before and after the match, and there were no significant hydroelectrolytic changes. It was possible to classify the low handicap polo as an exercise of short duration and varying intensity, considering the lack of change in the hydroelectrolytic balance. The exercise to which the animals were subjected is compatible with their athletic fitness.

\section{INTRODUCTION}

Polo is an equestrian sport with the effort alternating between low and high intensity (Gondim et al., 2013). Besides requiring heavy muscular and articular work, it requires moments of galloping with sudden pauses, high speed startups and sudden changes of direction (Ferraz et al., 2010; Bello et al., 2012).

The matches are held outdoors on grass field with two teams of four players each competing with the objective of scoring goal on the opponent's field. The matches last around an hour and a half, and are divided into 6 time (called chukker) of 7 minuteseach, with intervals between them. The animals do not play more than one chukker followed and should be changed every interval (Bello et al., 2013). Each equestrian polo player, according to his ability, has a handicap, ranging from -2 (less skilled players) to +10 (most skilled players), the values of the handicap of the team members are added together and the total is the total team handicap (Marlin \& Allen 1999).

Thermoregulation in horses during exercise is maintained by sweating, which causes loss of fluids and electrolytes (DiFilippo et al., 2009). The exercise is associated with changes in acid-base balance and hydroelectrolytic alterations in the blood, promoting metabolic acidosis (Aguilera-Teiero et al., 2000) or metabolic alkalosis due to the reduction of plasma $\mathrm{Cl}$; lost in sweat, and to the compensatory increase of plasma bicarbonate $\left(\mathrm{HCO}^{-}\right)$as a result of hyperventilation (Kingston et al., 1998; Aguilera-Tejero et al., $2000)$. Respiratory alkalosis or acidosis in prolonged submaxi- mal exercise is usually associated with respiratory alkalosis due to hypocapnia caused by hyperventilation (Kingston et al., 1998), progressive exercises of short duration are directly related to hypercapnia (Padilla et al., 2004). Interpreting data related to acidbase balance during exercise is a complex task, once it involves the interaction between different systems and variables (Kingston et al., 1998; Aguilera-Tejero et al., 2000).

Monitoring of changes in $\mathrm{pH}$, blood gases and derivatives (Kowal et al., 2008), in addition to hydroelectrolytic changes that occur as a result of an equestrian polo match, is an important protocol for characterization and assessment of hydroelectrolytic and acid-base imbalance (Farias et al., 2011). This strategy seeks to better understand the complexity of the effort during this exercise.

Thus, it is necessary to search for data to properly elucidate the alterations relative to the physiological demands and possible changes due to effort in this modality. Therefore the goal of this work was to define, from the analysis of blood gas and electrolyte changes, which were the physiological demands and possible changes resulting from effort in polo horses of low handicap, seeking to determine the type and intensity of exercise performed in this type of sport.

\section{MATERIAL AND METHODS}

Samples

This study evaluated seven healthy mixed breed horses, aged 
five to 22 years, weighing between 368 and $477 \mathrm{~kg}$ and height b.etween 1.47 and $1.61 \mathrm{~m}$. The studied animals were part of the polo squad of the $1^{\text {st }}$ Guard Cavalry Regiment ( $\left.1^{\text {st }} R C G\right)$, subjected to the same nutritional and health management and undergoing the same training protocol for at least one year. It was performed clinical and biochemical assessments and complete blood count to confirm the healthy condition of the animals. The procedures were approved by the Ethics Committee on Animal Experimentation of the Institute of Biological Sciences, University of Brasilia (21359/2010).

\section{Collection and processing of samples}

The venous blood samples were taken between the June and July, at two different times, two collections per animal: at rest (M0) and immediately after the polo match (MF). The collections at M0 were conducted where animals were stabled, one month before the match, in days previously set when they had not been exercised. Four $\mathrm{ml}$ of venous blood were used for hemogram (pocH-100ivDiff ${ }^{\circledR}$ ). For blood gas analysis it was used a portable chemistry analyzer (i-STAT CG8+ cartridge), hematocrit (HCT), hemoglobin ( $\mathrm{Hb})$, sodium, ionized calcium, potassi$\mathrm{um}$, potential of hydrogen $(\mathrm{pH})$, carbon dioxide pressure $\left(\mathrm{pCO}_{2}\right)$ and bicarbonate $\left(\mathrm{HCO}_{3}^{-}\right)$.

\section{Statistical analysis}

Data before (M0) and after (MF) exercise were presented as mean \pm standard deviation (mean $\pm \mathrm{SD}$ ). The normality was tested by the Kolmogorov-Smirnov test and evaluated by the paired t-test. To clarify the possible interference between the factors $\mathrm{pO}_{2}, \mathrm{pCO}_{2}, \mathrm{pH}$ e $\mathrm{HCO}_{3}$; at $\mathrm{M} 0$ and $\mathrm{MF}$, it was applied a Pearson correlation test (GraphPad Prism 2.6 for Windows, GraphPad Software, San Diego, CA, USA). P $\leq 0.05$ was considered as statistically significant.

\section{RESULTS}

The values remained within the normal reference range. Significant change $(p<0.05)$ was found between the two times evaluated only for the parameters $\mathrm{pCO}_{2}, \mathrm{pO}_{2}$ and $\mathrm{HCO}_{3}$. The partial pressure of $\mathrm{pCO}_{2}$ and the bicarbonate ion concentration decreased at the end of the match, while $\mathrm{pO}_{2}$ increased at this time. Increased concentrations of $\mathrm{Na}^{+}$and $\mathrm{Cl}^{-}$and reduced concentration of $\mathrm{K}^{+}$were observed, but all with $\mathrm{p}>0.05$. The mean values of results obtained for the parameters in the times (M0, MF) and the standard deviation of samples are presented in Table 1.

Table 1: Results (mean $\pm \mathrm{SD}$ ) of the analysis of blood gases ( $\mathrm{pCO}_{2}, \mathrm{pO}_{2}$ and $\left.\mathrm{HCO}_{3}^{-}\right)$, electrolytes $\left(\mathrm{Na}^{+}, \mathrm{Cl}^{-}, \mathrm{K}^{+}\right)$, and $\mathrm{pH}$, before (M0) and after (MF) the polo match.

Asterisk (*) in the same row indicates significant difference between the times $(p<0.05)$.

\begin{tabular}{|l|l|l|l|}
\hline Variable & $\mathrm{M0}$ & $\mathrm{MF}$ & $\begin{array}{l}\text { Normal } \\
\text { reference } \\
\text { range }\end{array}$ \\
\hline Blood Gases & & & \\
\hline $\mathrm{pCO}_{2}(\mathrm{mmHg})$ & $48,78 \pm 3,20$ & $39,64 \pm 3,91^{*}$ & $38-46$ \\
\hline $\mathrm{pO}_{2}(\mathrm{mmHg})$ & $38,31 \pm 3,93$ & $47,45 \pm 3,31^{*}$ & $35-40$ \\
\hline $\begin{array}{l}\mathrm{HCO}_{3}^{-} \\
\left(\mathrm{mmol}^{-} \mathrm{L}\right)\end{array}$ & $30,41 \pm 1,38$ & $23,55 \pm 2,81^{*}$ & $24-30$ \\
\hline $\mathrm{pH}^{\mathrm{Electrolytes}}$ & $7,41 \pm 0,01$ & $7,39 \pm 0,03$ & $7,32-7,44$ \\
\hline $\mathrm{Na}^{+}(\mathrm{mmol} / \mathrm{L})$ & $135,46 \pm 5,02$ & $137,18 \pm 2,45$ & $133-144$ \\
\hline $\mathrm{Cl}^{-}(\mathrm{mmol} / \mathrm{L})$ & $97,21 \pm 4,02$ & $98,71 \pm 3,36$ & $94-104$ \\
\hline $\mathrm{K}^{+}(\mathrm{mmol} / \mathrm{L})$ & $3,92 \pm 0,17$ & $3,68 \pm 0,34$ & $3,2-4,2$ \\
\hline
\end{tabular}

The correlations between bicarbonate and other variables at M0 and MF were shown in Figures 2 and 3. There was no pattern in the correlations between parameters.

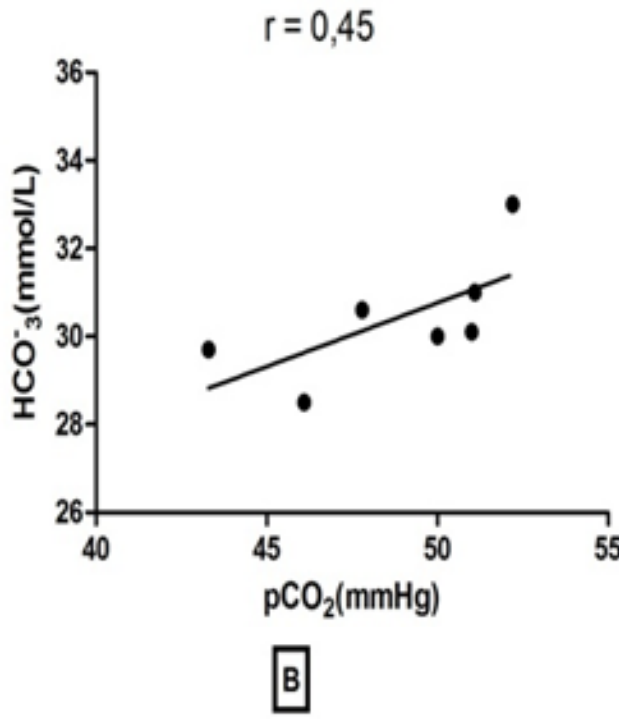

$r=0,03$

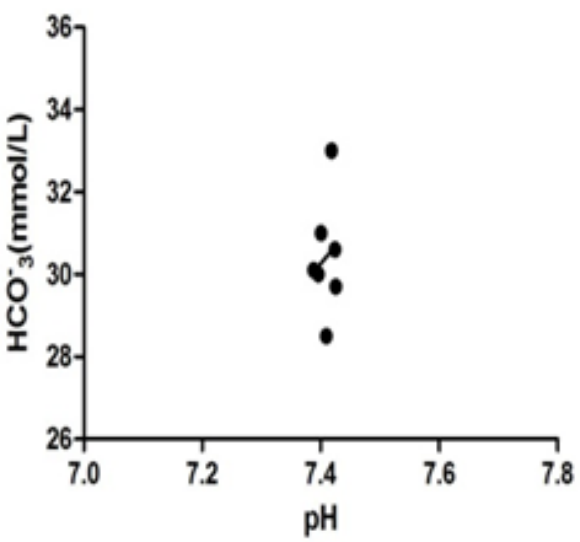

C

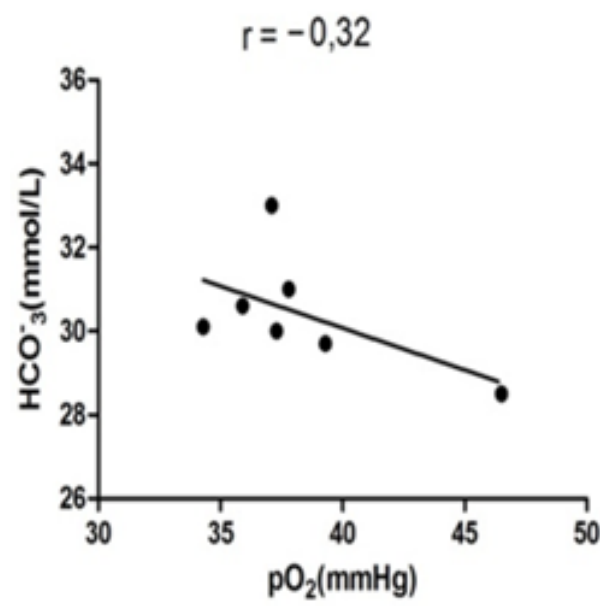

Figure 2. Pearson correlation between $\mathrm{pCO}_{2}$ and $\mathrm{HCO}_{3}^{-}(\mathrm{A})$, $\mathrm{pH}^{2}$ and $\mathrm{HCO}_{3}^{-}(\mathrm{B}), \mathrm{pO}_{2}$ and $\mathrm{HCO}_{3}^{-}(\mathrm{C})$ before the exercise (MO). $\mathbf{r}=$ Pearson correlation coefficient. 
回

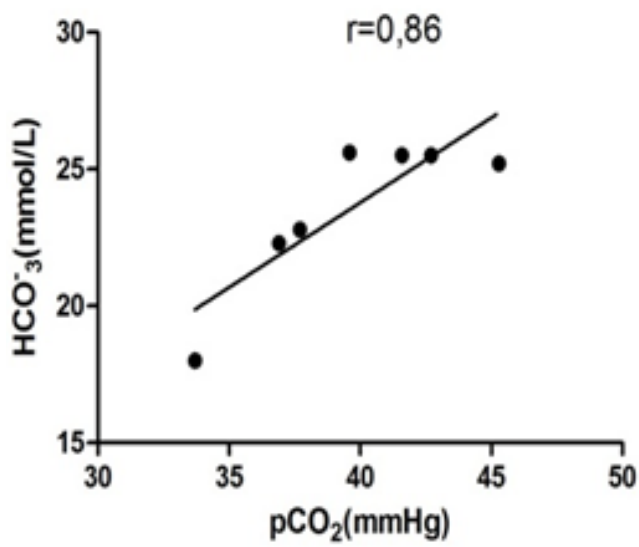

B

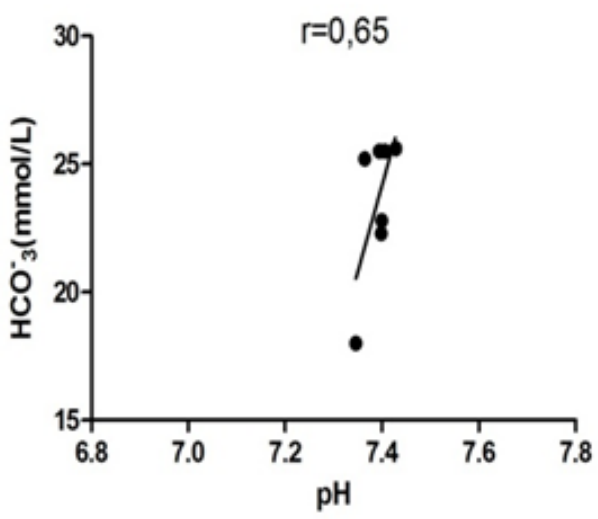

C

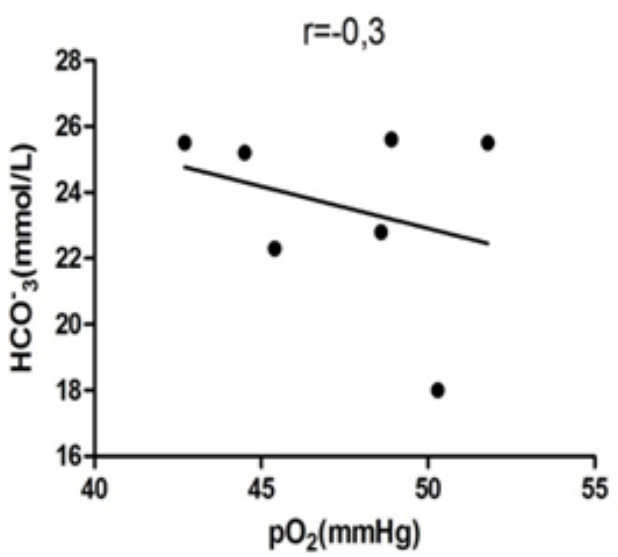

Figure 3. Pearson correlation between $\mathrm{pCO}_{2}$ and $\mathrm{HCO}_{3}^{-}(\mathrm{A})$, $\mathrm{pH}$ and $\mathrm{HCO}_{3}^{-}(\mathrm{B}), \mathrm{pO}_{2}$ and $\mathrm{HCO}_{3}^{-}(\mathrm{C})$ after the exercise (MF). $\mathbf{r}=$ Pearson correlation coefficient.

\section{DISCUSSION}

Equestrian polo is a team sport, the matches are held outdoors and presents moments of sudden increases in speed, with frequent and sudden changes of direction, all these characteristics make it a unique sport, whose analyses of physiological demands are complex. In this study, mainly the choice of the methods proved effective, since there was no difficulty in carrying out collections or samples analysis.

Regarding blood electrolytes $\mathrm{Na}^{+}, \mathrm{Cl}^{-}$and $\mathrm{K}^{+}$, there were no significant changes between the times. This corroborates the findings of other studies performed with low handicap polo horses (Bello et al., 2012), which detected no significant loss of body weight after polo match, suggesting that the animals suffered no significant dehydration, i.e., water loss, and consequent electrolyte loss. Physical activity promotes increased production of heat, and sweating is the main route of heat dissipation, and the sweat volume varies according to the duration and intensity of exercise (DiFilippo et al., 2009). In general there are no remarkable changes in electrolyte balance during maximum intensity exercise, due to the short period of this effort (Silva et al., 2009). In this way, the low handicap polo was not characterized as prolonged or intense, unable to promote sweating that resulted in significant depletion of ions.

The reduction in $\mathrm{pCO}_{2}$ was similar to that found in jumping animals (Aguilera-Tejero et al., 2000) and polo animals (Ferraz et al., 2010). When the effort is prolonged the organism seeks ways to maintain homeostasis, with hyperventilation being an important mechanism. Thereby, at the moment immediately after exercise, as there is no metabolic demand, elimination of $\mathrm{CO}_{2}$ through respiration exceeded the buildup that was produced during the exercise, lowering its level to below the resting level (Aguilera-Tejero et al., 2000).

Despite the significant reduction, $\mathrm{HCO}_{3}$ - values were within the physiological range considered for the species (20-28 $\mathrm{mmol} / \mathrm{L}$ ) (Carlson et al., 1997). This reduction, similar to that observed in jumping animals, can be attributed to compensatory mechanisms related to hyperventilation due to the exercise (AguileraTejero et al., 2000). For Ferraz et al. (2010), the significant reduction of this parameter in high handicap animals, with the occurrence of metabolic acidosis, allowed classifying it as a high intensity exercise. The reduction in the concentration of $\mathrm{HCO}^{3-}$ in the low handicap polo could lead to metabolic acidosis, if it was not the compensation caused probably by the reduction of $\mathrm{pCO}_{2}$ (Aguilera-Tejero et al., 2000). This situation can be understood by the requirement of the animals during the match.

There was no significant change in $\mathrm{pH}$, between the times, evidencing the efficiency of compensatory mechanisms, such as the relationship between $\mathrm{HCO}_{3}{ }^{-}$and $\mathrm{pCO}_{2}$ in maintaining the $\mathrm{pH}$ within a normal range during exercise. This corroborated the findings of Aguilera-Tejero et al. (2000) in jumping animals. The effort performed in low handicap polo match was not able to induce acid-base disturbance until the time of evaluation. Nevertheless, with the increase in exercise intensity certainly acidosis would develop (Dumont et al., 2012).

Immediately after the match, the animals showed an increase in $\mathrm{pO}_{2}$ values, as also found by DiFilippo et al. (2009), when evaluated endurance animals, and Silva et al. (2009) in animals subjected to submaximal and maximal exercise on treadmill. Even considering different equestrian sports, it was possible to understand that the most likely cause of this increase was the alveolar hyperventilation in response to a decrease in the concentration of $\mathrm{HCO}_{3}$ - caused by physical activity (DiFilippo et al., 2009).

The correlation between $\mathrm{pCO}_{2}$ and $\mathrm{HCO}_{3}^{-}$was positive and high, and can be explained from the respiratory mechanism of $\mathrm{pH}$ control. Among the buffering mechanisms against rapid changes in $\mathrm{pH}$, the one that responds more quickly is the respiratory, acting as a bicarbonate/carbonic acid buffering system (Kingston and Beyly, 2004). $\mathrm{CO}_{2}$ is transported in the blood in the form of a volatile acid, carbonic acid, and to turn into this acid, $\mathrm{CO}_{2}$ undergoes hydration. The carbonic acid then dissociates into water $\left(\mathrm{H}_{2} \mathrm{O}\right)$ and bicarbonate $\left(\mathrm{HCO}_{3}{ }^{-}\right)$. When there is excess acid in the blood, the bicarbonate from the dissociation of carbonic acid combines with free $\mathrm{H}^{+}$ions, again forming the carbonic acid which, by being in excess at that time, will dissociate into $\mathrm{CO}_{2}$ and $\mathrm{H}_{2} \mathrm{O}$; the $\mathrm{CO}_{2}$ produced in this reaction is then eliminated by the lungs through breathing (Kingston and 
Beyly, 2004). It was expected a high correlation between these factors, before and at the end of the exercise, indicating the effectiveness of this mechanism to restrain metabolic changes, as demonstrated by the absence of changes in $\mathrm{pH}$. It should be noted that the lack of linear correlation between $\mathrm{pH}^{\mathrm{H}} \mathrm{HCO}_{3}{ }^{-}$and $\mathrm{pO}_{2}$ and $\mathrm{HCO}_{3}$ - does not mean that there may be another type of correlation between them, like the exponential (Figueiredo Filho and Silva Júnior, 2009).

When comparing the results between animals of low and high handicap (Ferraz et al., 2010), which showed metabolic disorders, it was possible to suppose that the exercise imposed to low handicap animals was not enough to induce acid-base and hydroelectrolytic imbalance. It should be emphasized that the high handicap animals underwent more intense physical training, ensuring adaptation to the exercise. Thus it would be expected that these animals better adapted to the type of exercise would not show significant metabolic changes and, conversely, those low handicap horses - theoretically less suited to the effort practiced - would show such changes, which did not occur. Especially, the handicap is determined in relation to the ability of each horseman, so those less skilled require less from the athletic potential of the animal, i.e., less effort. Consequently, by promoting metabolic changes little striking when compared to animals used by horsemen with high handicap. In other words, regardless of the animal adaptation to the type of effort performed, it was observed that the human factor influenced on the intensity of the effort performed by the animal.

Coinciding with Bello et al. (2012), the low handicap polo can be characterized as a sport of mixed intensity. However, Ferraz et al. (2010), classified this as a high intensity activity, based on the significant reduction of $\mathrm{HCO}_{3}^{-}, \mathrm{pCO}_{2}$ and $\mathrm{pH}$. For Kingston and Bayly (2004), only the measurement of $\mathrm{pH}, \mathrm{HCO}_{3}$ and $\mathrm{pCO}_{2}$ without measuring the maximal oxygen consumption $\left(\mathrm{VO}_{2 \max }\right)$, it would be inaccurate to draw definite conclusions about the intensity of the exercise. Otherwise, the exact determination of the degree of depletion of metabolic reserves and physical requirements of the animals should take as reference other variables, such as the climatic ones.

\section{CONCLUSION}

The low handicap polo is classified as an exercise of short duration and varying intensity (mild to moderate), since there were no changes in hydroelectrolytic balance. The blood gas variations are related to the type of sport, or according to the variations in the ability of oxygen consumption of each animal. Thus, the type of exercise to which the animals were submitted is compatible with their athletic fitness.

\section{REFERENCE}

Aguilera-Tejero, E., Estepa, J. C., López, I., Bas, S., Mayer-Valor, R., \& Rodríguez, M. (2000). Quantitative analysis of acid-base balance in show jumpers before and after exercise. Research in veterinary science, 68(2), 103-108. | Bello, C. A., Dumont, C. B., Souza, T. C., Palma, J. M., Lima, E. M., Godoy, R. F., ... \& Meryonne, M. (2012). Avaliação eletrocardiográfica de equinos após exercício de polo (baixo handicap). Pesquisa Veterinária Brasileira,32(1), 47-52. | Carlson, G. P. (1997). Fluid, electrolyte, and acid-base balance. Clinical biochemistry of domestic animals, 5, 485-516. | Di Filippo, P. A., Gomide, L. M. W., Orozco, C. A. G., da Silva, M. A., Martins, C. B., de Lacerda Neto, J. C., \& Santana, A. E. (2009). alterações hemogasométricas e eletrolíticas de cavalos da raça árabe durante prova de enduro de 60 km. Ciência Animal Brasileira, 10(3), 840-846. | Kowal, R. J., Cascardo, B., Summa, R. P., Cury, L. J., Neto, J. M., \& Almosny, N. R. P. (2008). Avaliação dos valores gasométricos em cavalos (Equus caballus) da raça Puro-Sangue-Inglês (PSI) submetidos a teste de esforço em esteira ergométrica. Revista Brasileira de Ciência Veterinária,15(1). | Dumont, C. B., Leite, C. R., Moraes, J. M., Moreira, M., Moscardini, A. R., Godoy, R. F., \& Lima, E. M. (2012). Osmolaridade, ânion gap, potencial hidrogênionico e íons plasmáticos mensuráveis de equinos Puro Sangue Árabe finalistas em provas de enduro de 90 Km. Pesq. Vet. Bras, 32(6), 542-546. | de Farias, S. K., Ribeiro Filho, J. D., Donner, A. C., Dantas, W. D. M. F., \& Gomes, C. L. N. (2011). Hemogasometria e ânion gap em equinos tratados com soluções eletrolíticas enterais contendo diferentes fontes de energia.Ciência Rural, 41(9), 1587-1592.| Ferraz, G. C., Soares, O. A. B., Foz, N. S. B., Pereira, M. C., \& QUEIROZ-NETO, A. (2010). The workload and plasma ion concentration in a training match session of high-goal (elite) polo ponies. Equine Veterinary Journal,42(s38), 191-195. | Figueiredo Filho, D. B., \& Silva Junior, J. A. (2010). Desvendando os Mistérios do Coeficiente de Correlação de Pearson (r). Revista Política Hoje,18(1). | Gondin, M. R., Foz, N. S., Pereira, M. C., Flagliari, J. J., Orozco, C. A., D’Angelis, F. H., ... \& Ferraz, G. C. (2013). Acute Phase Responses of Different Positions of High-Goal (Elite) Polo Ponies. Journal of Equine Veterinary Science, 33(11), 956-961. | Kingston, J. K., \& Bayly, W. M. (1998). Effect of exercise on acid-base status of horses. The Veterinary clinics of North America. Equine practice,14(1), 61-73. | Marlin, D. J., \& Allen, J. C. R. (1999). Cardiovascular demands of competition on low-goal (non-elite) polo ponies. Equine veterinary journal, 31(5), 378-382. | Padilla, D. J., McDonough, P., Kindig, C. A., Erickson, H. H., \& Poole, D. C. (2004). Ventilatory dynamics and control of blood gases after maximal exercise in the Thoroughbred horse. Journal of Applied Physiology, 96(6), 2187-2193. | Silva, M. A., C. B. Martins, L. M. Gomide, R. M. Albernaz, J. C. Lacerda-Neto and A. Queiroz-Neto. (2009). Determinação de eletrólitos, gases sanguíneos, osmolaridade, hematócrito, hemoglobina, base titulável e anion gap no sangue venoso de equinos destreinados submetidos a exercício máximo e submáximo em esteira rolante. Arquivo Brasileiro de Medicina Veterinária e Zootecnia, 61(5), 1021-1027.| 